\title{
FINANCIAL PERFORMANCE OF SLOVENE CASINO INDUSTRY: COMPARATIVE ANALYSIS OF REGULAR CASINOS AND CASINO SALOONS
}

\author{
Mateja Jerman, Associate Professor ${ }^{1}$ \\ DOI: https://doi.org/10.31410/tmt.2018.651
}

\begin{abstract}
The casino industry has an important role for the Slovene economy. However, in the last decade the Association of gambling in Slovenia highlights that the situation in the industry in terms of economic profitability is getting worse. In Slovenia, casinos are divided to regular casinos, which can organize all special games of chance and casino saloons that can organize only a limited part of them. Since in the past there were found differences in their financial performance, the paper aims to perform a comparative analysis of their performance, to find out if financial problems refer to the whole industry or only to a part of it. The results show that in the recent period there was no significant difference in financial performance between regular casinos and casino saloons. However, we found a statistically significant difference in the return on equity considering times before the financial crisis and the period 2013-2017. Lately the financial performance of casinos is on average significantly worse than it was in the past. The results of this study draw attention to the fact the Strategy of the development of games of chance in Slovenia from 2010 has to be implemented.
\end{abstract}

Keywords: casino industry, performance, financial analysis, Slovenia.

\section{INTRODUCTION}

I

n accordance with Sallaz [1] since 1990s we have seen a global convergence from gambling prohibition to gambling legalization and contemporarily a divergence on how gambling industries are structured and regulated. Worldwide there are countries where casinos are in public ownership and countries where government legalized a competitive, corporate casino industry. Eadington [2] argues that in the European Union many gaming industries are under monopoly protection which is characterized by the state ownership or a significant state influence. Thus, it is not surprising that the majority of gaming industries within European Union is not highly competitive and has evidenced slow growth or even stagnation in terms of revenues.

Gambling industry is an important branch of tourism sector in Slovenia. The importance of the gambling industry in Slovenia is based on the fact that among European countries, Slovenia stands out for a high percentage of gross gambling revenues in GDP and a high proportion of gross casinos revenue in gross revenues of the entire gambling industry [3]. According to the latest publicly available data from 2009, the share of regular casinos in the whole Slovene gambling industry was $47 \%$ and the share of casino saloons was $35 \%$. The share of classic gambling was only $18 \%$ [3]. In times before the financial crisis the industry generated the highest added value per employee within Slovene tourism industry and created 256 million $€$ of revenues (2009) which classified it as the third largest (after the hotel industry and travel agencies) tourism sector in Slovenia [4].

University of Primorska, Faculty of management, Cankarjeva 6, 6000 Koper, Slovenia 
Since 1964, when the first casino (Casino Portorož) started to operate, the Slovene casino industry did not evidence notable financial problems until the passage into the new century. ${ }^{2}$ Compulsory settlements of Casino Bled (2003) and Casino Portorož (2008 and 2013), followed by bankruptcy of Casino Maribor (2009) and Casino Ljubljana (2010) have drawn attention. Only three out of seven state owned companies did not have major financial problems. ${ }^{3}$ On the other hand new establishments of casino saloons in the private ownership were evidenced in the period from 2002 to 2009 (the number of casino saloons in this period increased from 10 to 34). In 2018 the number of casino saloons amounts to 26 .

In accordance with the fact that on one hand regular casinos were chasing their activity and on the other new casino saloons were established, the paper aims to find out if any difference exists in their financial performance. To this end, a comparative analysis of financial performance between regular casinos and casino saloons for the period 2013-2017 will be performed. Our analysis will be grounded on the DuPont performance measurement framework, which is based on ROE (return on equity) as the most important indicator for owners, showing their return on investment.

Considering the fact that the Association of gambling in Slovenia is increasingly exposing the difficulties in the business operations of companies in the casino industry [5] the paper also aims to perform a comparative analysis of financial performance of the industry, taking into consideration times before the economic crisis and the period after the crisis.

The reminder of the paper is as follows. The second chapter presents the legal and tax characteristics of companies organizing special games of chance in Slovenia, emphasizing the difference between regular casinos and casino saloons. The third chapter highlights key characteristic of the Slovene casino industry. In the fourth chapter past and present results of the industry are pointed out. The analysis of financial performance of Slovene casino industry is performed in the fifth chapter. The paper ends with concluding remarks in the sixth chapter.

\section{GENERAL LEGAL AND TAX CHARACTERISTICS OF REGULAR CASINOS AND CASINO SALOONS}

The system of organizing gaming in Slovenia is regulated with the 2011 Gaming Act, which was amended in 2012 and 2014. Despite the fact that the first casino was opened already in 1964 the first Gambling Act was issued only in 1995. The latter for the first time settled down requirements for granting of concessions and for the first time allowed even the domestic citizens to visit casinos. In accordance with the first Gambling Act only regular casinos, where the majority holding has to be represented by the government or local authorities were allowed to obtain a concession. At that time casinos in the private ownership were not feasible. The amendments of the Act in 2001 introduced the possibilities for granting of concessions for casinos even in private ownership [6].

The Slovenian legislation distinguishes two types of casinos; i.e. a regular casino and casino saloon. The most important difference between them is their ownership, since a regular casino

$2 \quad$ Since Slovenian independence the whole industry recorded losses only in 1995. Even in 1995 only Casino Portorož recorded a 0.5 million losses, while Casino Bled, Casino HIT and Casino Ljubljana evidenced a positive income.

3 The authors would like to notice that even Casino Hit, Casino Kobarid and Hit Šentilj recorded a negative income in 2008 and 2009. 
has to be established in the form of public limited company and has to be at least in $51 \%$ government ownership, while a casino saloon is in private ownership (established as a limited liability company or public limited company). The funding structure is not the only characteristic that distinguishes them. Moreover, casino saloons are not allowed to offer table games as regular casinos and are limited to a maximum of 200 slot machines.

Both, regular casinos and casino saloons pay gambling taxes and concession fees. The concession fee they are paying differs between them. The Gambling act from 2003 defined different concession fees for regular casinos and casino saloons. For the concessionaires who applied for the big concession (i.e. regular casinos) the concession fee amounts to $5 \%$ of the taxable basis for each of the seventh types of games that can be performed in regular casinos (the only exception is the sixth type). The taxable basis for the first type of games is represented by the amount of revenues, while in all other cases (except the seventh type) the basis is represented by the difference between pay-inn and pay-out. Even in the case of the seventh type, the tax base is represented by the difference between pay-inn and pay-out, the exception relates the associated concession fee. In the case of casino saloons, the concession fee is fixed and amounts to $20 \%$. On the other hand, regular casinos apply a progressive tax rate which varies from $5 \%$ to $20 \%$ of tax base. Therefore, the calculation of tax base for both; regular casinos and casino saloons is the same, the difference relates the concession fee which significantly differs between them.

In accordance with the latest publicly available data [3] for 2009 Slovene casino saloons did pay (gambling tax and concession fee) on average 38\% of taxes, while regular casinos paid from $23 \%$ to $32.4 \%$ of taxable basis. This data indicates that regular casinos have more favorable tax rates than casino saloons.

Since 2001, when the Gaming Act began to allow the operation of casino saloons, the structure of the generated revenues in the industry has changed significantly. From 2002 to 2009, the share of regular casinos in the total gross revenues (of special games of chance) decreased from 90 to $59 \%$, while the share of casino saloons increased to $41 \%$ in 2009 [3].

\section{CHARACTERISTICS OF THE SLOVENE CASINO INDUSTRY}

The period 2002-2006 was characterized by a rapid increase in the number of casino saloons, which was influenced by the domestic economic situation and the one in neighbouring Italy. Slovenian casino industry is mainly focused at foreign, especially Italian guests, which is why the financial performance depends mainly on the political and economic situation in neighbouring Italy [3]. Interestingly, although Slovenian casinos depend mainly on the Italian guests, during the financial crisis Slovenian casino industry recorded poor business results, while the performance of Italian casinos in the period 2008-2012 was not statistically significantly different [7]. The biggest competition for the Slovenian companies, organizing special games of chance, is the offer of neighbouring countries, especially Italy, Austria and Croatia [3].

In the past, Statistical Office of the Republic of Slovenia monitored the visits of Slovenian casinos, but this is no longer monitored since 2009 [9]. According to the latest publicly available data, the majority of guests are foreign guests. In the period 2002-2009, the importance of foreign guests was on average higher than $70 \%$. The highest share of foreign guests was recorded in regular casinos and casino saloons near the Italian border (some casinos also accounted for over $90 \%$ ). In the casinos inside the country, the share of foreign guests was considerably lower [3]. 
The latest data about the structure of tourists in Slovenia for 2017 show that in the structure of tourist arrivals foreign tourists represent a predominant share of $72 \%$, and a $68 \%$ share in the structure of overnight stays. In the structure of foreign tourist arrivals, the most important were those from Italy, followed by tourists from Austria, Germany and Croatia - representing a 30\% share in the structure of foreign tourist arrivals [8]. According to the presented data, the structure of tourists in Slovenia is favorable for the casino industry, since the most frequent visitors of casinos in terms of their nationality are also the most frequent tourists in Slovenia. Although the trend of tourists visiting Slovenia has been very favorable in recent years, it has already been pointed out (in the Strategy of the development of games of chance in Slovenia in 2010) that in view of the given volume of demand, the market is saturated. Therefore, in line with the demand, the number of active concessions is too large [3]. Therefore, the Slovenian Government announced that it would reduce the number of concessions granted. It was planned that by 2013, there will be no more than 35 casinos, and by 2020, a maximum of 30 [3]. Although the number of concessionaires today is actually lower than it was in the past, this is not the result of an active policy of limiting the number of concessions by the state, but the cessation of the business of certain companies on the market. Since 2010, Slovenia has not actively implemented the strategy in this area.

Assaf et al. [10] explored performance drivers in the Slovene casino industry. Their analysis is based on data of 28 major casinos (including regular casinos and casino saloons) from the period 2004-2008. They found that there is a statistically significant difference in financial performance of large casinos in comparison with smaller ones, casinos which operate near the Slovene boarder and finally, casinos which operate as a group in comparison with those that operate individually.

Findings of Pahor [11] regarding the social costs and economic benefits of the gambling industry in Slovenia suggest that in general benefits outweigh the cost. The reason concerns the fact that costs are spread (the major part of visits represent foreign guests), while benefits are mostly concentrated locally. These results were found for a city that can be characterized as the capital of gambling activities in Slovenia. Given that visitors of Slovene casinos are mainly foreign guests, we believe that the costs are spread and the benefits are local.

\section{KEY FIGURES ABOUT THE PAST AND PRESENT OPERATIONS}

Since 1995 when the industry as a whole recorded loss, no major problems were evidenced until 2007. If we compare the increase of assets (the increase was present until 2009) with the decrease of equity (present since 2007) we can conclude that the growth of business was financed with external financial resources (in the case of casino industry predominately bank loans). In the funding structure the share of debt increased significantly. The increase of assets was not followed by a similar or even higher growth of revenues. In 2007 and 2008 when the value of assets was still increasing, revenues recorded already a minor decrease.

Before the appearance of the latest financial crisis in Slovenian economy in 2009, the casino industry evidenced the highest ROE in 2005 (15.4\%), but the latter decreased significantly in subsequent years. In 2005 the casino industry was the most profitable one within all sectors in the Slovene tourism industry. However, in the following years, the results of the industry deteriorated significantly (much more than in other tourism sectors). 
To understand the reasons that lead to worse results in the industry and moreover analyze possible differences between regular casinos and casino saloons, firstly, the main figures about the industry are presented.

Data on the branch's operations show (Figure 1) that in the latest five-year period the value of total assets decreased by $14.5 \%$, which means that the industry did not grow, but reduced the volume of its business. More promising is the value of equity, which shows that the owners' investment increased by $20.0 \%$. The relationship between equity and debt financing in the industry has improved considerably. If in 2013 the share of equity financing was on average $30.1 \%$, it increased to an average value of $42.6 \%$ in 2017 (the source of data is [12]). In spite of the improvement, the share of equity financing of the industry is still worse than the economy's average, with a share of 47.7\% [13]. Net sales revenues did not change significantly during the period 2013-2016 (growth was negligible), and have slightly increased only in 2017. Compared to 2013, casinos generated only 5.8\% more sales revenues in 2017. Based on presented data, we find that in the period 20132017 the value of total assets did not increase, but has even decreased (the industry is shrinking its business), and the growth in sales revenue was not encouraging, as it amounted to $5.8 \%$.

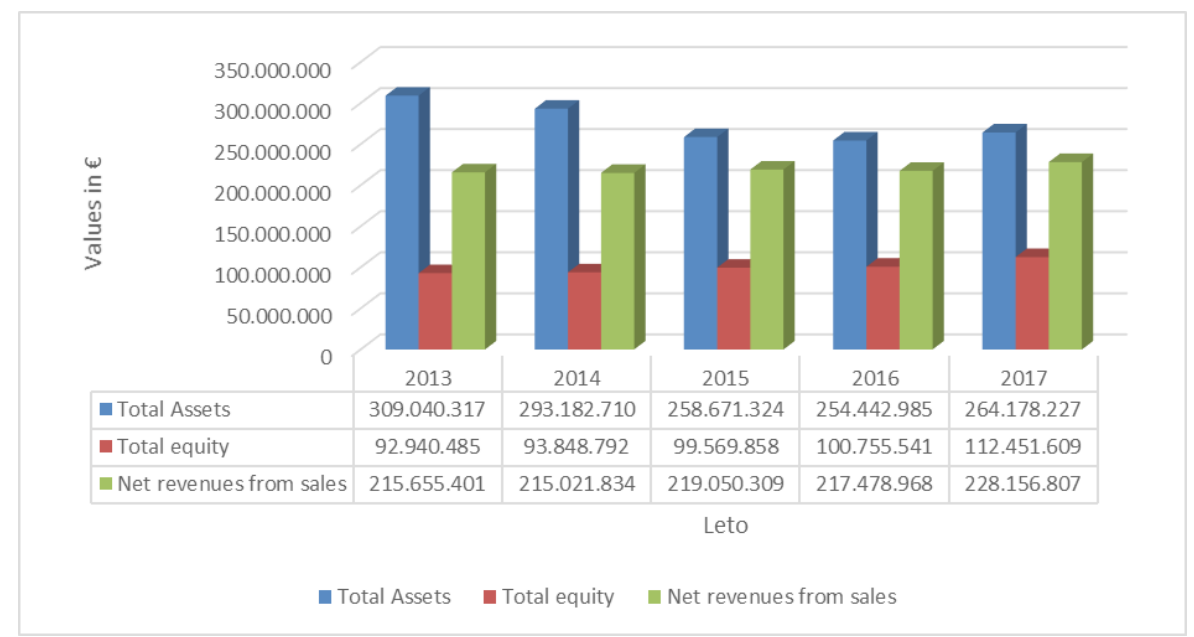

Figure 1: Value of total assets, value of equity and net revenues from sales in the period 2013-2017.

Source: Data are gathered from the database of [12]

Taking into consideration also the net income (Table 1), we find that the net profit of the industry in 2013 was negative. The situation improved in the following years, when the industry generated a positive income. The circumstances in the industry have improved after the end of the financial and economic crisis. According to Repinec [5] the number of employees in the industry fell significantly in times of financial crisis. However, the added value per employee in the casino industry was higher than the economy's average in the whole period of our analysis (2013-2017). In 2017 it amounted to $€ 47,970$, while the economy’s average was 43,154 $€$ [13].

\begin{tabular}{|l|r|r|r|r|r|}
\hline & \multicolumn{1}{|c|}{2013} & \multicolumn{1}{c|}{2014} & \multicolumn{1}{c|}{2015} & \multicolumn{1}{c|}{2016} & \multicolumn{1}{c|}{2017} \\
\hline Net income (in $€$ ) & $-6,853,230$ & $3,619,587$ & $10,888,123$ & $7,914,371$ & $14,419,547$ \\
\hline Value added per employee (in $€$ ) & 44,926 & 47,421 & 49,489 & 47,223 & 47,970 \\
\hline
\end{tabular}

Table 1: Value of net income and value added per employee in the period 2013-2017.

Source: Data are gathered from the database of [12] 


\section{FINANCIAL PERFORMANCE ANALYSIS OF THE SLOVENE CASINO INDUSTRY}

The purpose of our analysis is to find out if there is any difference in financial performance of regular casinos and casino saloons in Slovenia and if they do differ what are the reasons that lead to differences in their financial results. Moreover, the authors aim to perform a comparative analysis of financial performance of the industry, taking into consideration times before the economic crisis and the period after the crisis.

\subsection{Methodological framework}

The presented analysis includes companies which operate within the Standard classification of activities R92.001 - Activities of casinos. The sample includes 28 corporations that had an active license for gambling on the $1^{\text {st }}$ September 2018. Among these there are 3 corporations that owe regular casinos and 25 corporations owing casino saloons. Financial data was obtained from the GVIN financial database [14]. All data was collected from financial statements prepared for external reporting purposes.

\section{Hypothesis development}

The analysis of Ivankovič and Jerman [15] for the period 2005-2009 provided evidence that casino saloons outperformed regular casinos. Casino saloons were much more profitable in terms of ROE than the regular casinos. The differences mainly descend from the funding structure and asset turnover ratio. Since from 2009 the Slovenian Government did not implement any significant actions that would lead to changes in the sector, we believe that: The financial performance of regular casinos and casino saloons differs in the period 2013-2017.

The Association of gambling in Slovenia is increasingly exposing financial problems of the industry, whereby, as a reason for the problems, it points to the increasingly less competitive economic environment [5]. Considering this fact, the question arises whether these problems are present only in individual companies or the performance of the industry in recent times is worse than it was in the past. Therefore, we will examine the second hypothesis: The performance of Slovenian casinos in the period since the end of the financial crisis is worse than it was before the financial crisis.

\section{Methods in use}

The first hypothesis will be tested on data from the five-year period 2013-2017. Financial performance of selected companies will be determined using financial ratios as follows: ROE (return on equity), ROA (return on assets), share of equity, net profitability and asset turnover. All these ratios derive from the DuPont performance measurement system presented in Figure 2. In accordance with the DuPont framework of ratios ROE is the crucial performance indicator. It is a product of ROA and funding structure. To a higher ROE leads a higher ROA and a lower "asset to equity" ratio. A lower share of equity in the funding structure leads to a higher ROE. ROA is a product of net profitability and asset turnover. A higher ROA is a result of a higher net profitability and a higher asset turnover.

The first hypothesis testing is based on financial ratio ROE. The profitability of selected companies will be calculated with ROE as the most important ratio from the owner's perspective 
(calculated as net income for the financial year divided by the average value of total equity (total equity from the beginning of the financial year plus total equity from the end of the financial year divided by two). More in depth analysis follows the DuPont system of financial ratios. The comparative analysis of financial performance is analyzed more in details with ROA (return on assets, which will be calculated as net income for the financial year divided by the average value of total assets (total assets from the beginning of the financial year plus total assets from the end of the financial year divided by two), financial ratio "assets / equity", net profitability ratio (calculated as net income for the financial year divided by total revenues for the financial year) and asset turnover (calculated as total revenues divided by total assets).

For the purpose of second hypothesis testing, a non-parametric paired sample t-test will be performed. The mean value of ROE will be compared between the period before the crisis and the time after the crisis.

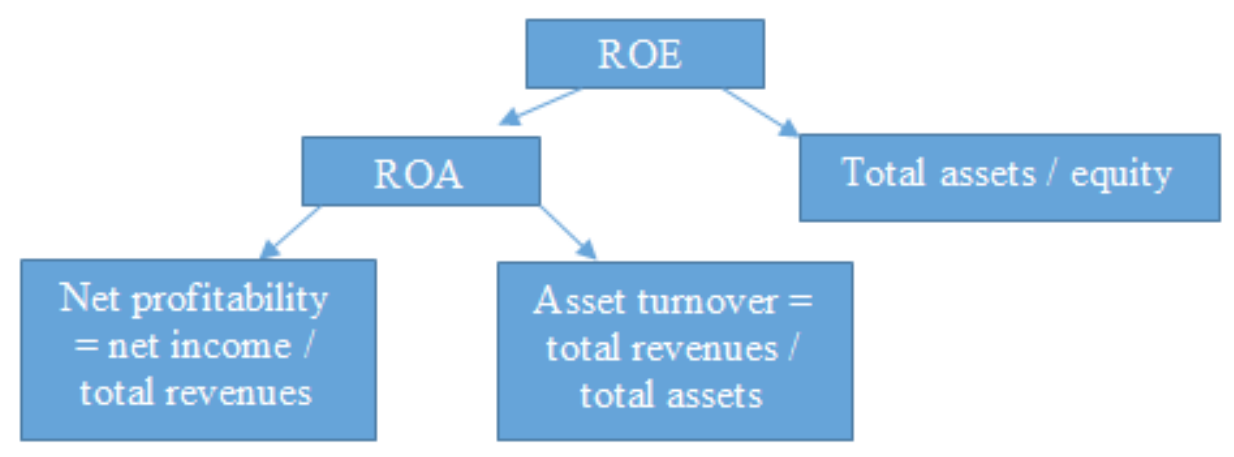

Figure 2: DuPont performance measurement system

\subsection{Data analysis and results}

Firstly, the analysis of ROE will be performed. Figure 3 shows the average values of ROE for regular casinos and casino saloons for the period 2013-2017. As shown, in the first two years of our analysis the casino saloons on average outperformed regular casinos, while in the following years the situation was just the opposite. The authors would like to notice that there are significant differences between casinos; since there is a high standard deviation among them (more detailed data is presented in Appendix 1). On average regular casinos evidenced a negative ROE in 2013 and 2014, followed by a positive ROE in the period 2015-2017. On the other hand, casino saloons had a negative ROE in 2013 , followed by a positive one in the subsequent years. These results show that the owners' investments were not profitable at the beginning of the period, while the situation improved in the subsequent years.

A more in depth analysis shows mixed results in the case of ROA. In regular casinos ROA was negative in the first two years of analysis and positive in the years that followed. In the case of casino saloons ROA was negative in two out of five years and positive in the remaining three years. Even in the case of ROA the standard deviation is relatively high. More detailed data about ROA is presented in Appendix 2.

A much more evident difference between the two groups of casinos is present in their funding structure. The average share in the casino industry is similar to the economy's average. A more in detail analysis shows that the average share of equity is significantly higher in the case of casino saloons in comparison to regular casinos. In the case of casino saloons, it ranges between 
44.74\% in 2013 and $55.66 \%$ in 2017. On the other hand, in regular casinos the share amounted to $12.53 \%$ in 2013 and rose to a share of $24.09 \%$ in 2017 (Appendix 3), showing that regular casinos have a relatively low share of equity.

A deeper analysis of ROA shows that the differences in the net profitability of revenues are similar to before mentioned differences in ROA. On the other hand, the asset turnover ratio shows that casino saloons outperformed regular casinos in all years of our analysis. Regular casinos evidenced a lower turnover ratio, indicating that casino saloons generate higher revenues with the given extent of assets and are thus more efficient (more detailed data in Appendix 5).

Based on our results we cannot state that there is a significant difference in the ROE between regular casinos and casino saloons in the period 2013-2017. However, a more in depth analysis has shown that they differ in terms of funding structure (casino saloons use more equity financing) and turnover ratios. In spite of these differences the ROE is not significantly higher in regular casinos, as we expected. We believe that we found no significant differences in ROE between the two groups of casinos since regular casinos were involved in processes of compulsory settlements, which has led to their rationalization.

A more in depth analysis shows mixed results in the case of ROA. In regular casinos ROA was negative in the first two years of analysis and positive in the years that followed. In the case of casino saloons ROA was negative in two out of five years and positive in the remaining three years. Even in the case of ROA the standard deviation is relatively high. More detailed data about ROA is presented in Appendix 2.

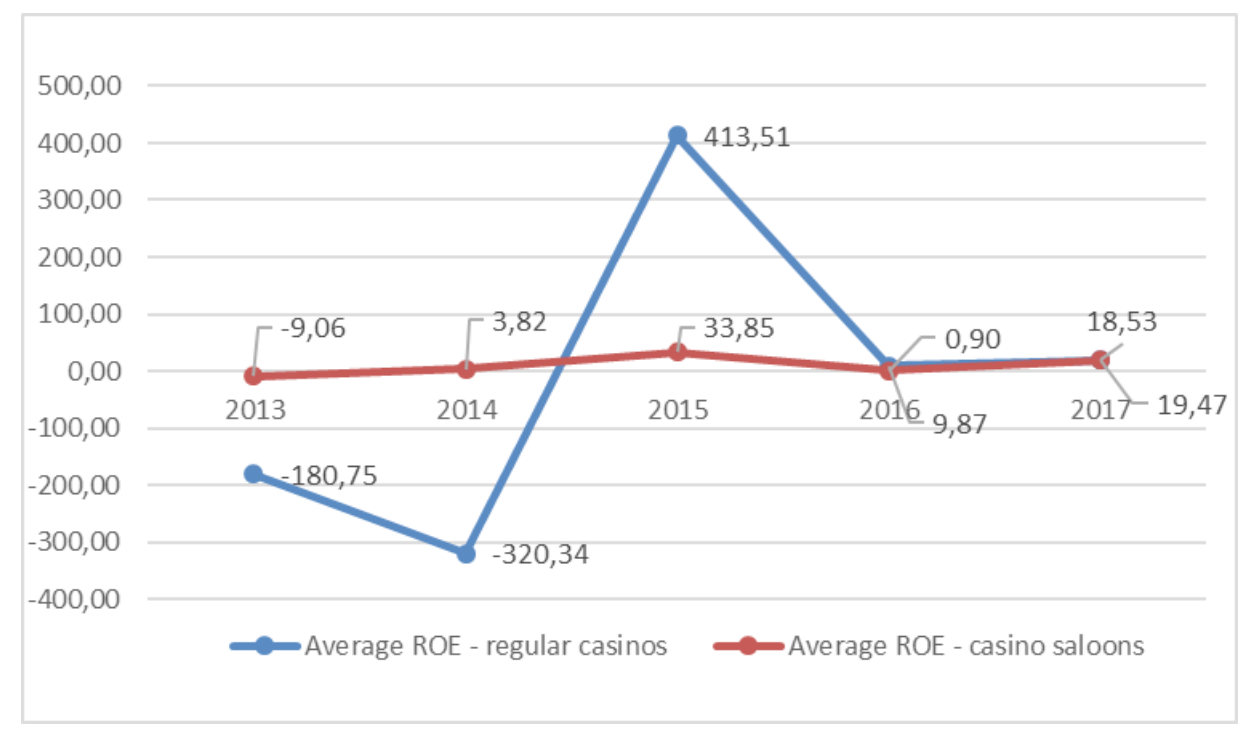

Figure 3: Average ROE of regular casinos and casino saloons for the period 2013-2017 (in \%) Source of data: [14]

A much more evident difference between the two groups of casinos is present in their funding structure. The average share in the casino industry is similar to the economy's average. A more in detail analysis shows that the average share of equity is significantly higher in the case of casino saloons in comparison to regular casinos. In the case of casino saloons, it ranges between $44.74 \%$ in 2013 and $55.66 \%$ in 2017. On the other hand, in regular casinos the share amounted to $12.53 \%$ in 2013 and rose to a share of $24.09 \%$ in 2017 (Appendix 3), showing that regular casinos have a relatively low share of equity. 
A deeper analysis of ROA shows that the differences in the net profitability of revenues are similar to before mentioned differences in ROA. On the other hand, the asset turnover ratio shows that casino saloons outperformed regular casinos in all years of our analysis. Regular casinos evidenced a lower turnover ratio, indicating that casino saloons generate higher revenues with the given extent of assets and are thus more efficient (more detailed data in Appendix 5).

Based on our results we cannot state that there is a significant difference in the ROE between regular casinos and casino saloons in the period 2013-2017. However, a more in depth analysis has shown that they differ in terms of funding structure (casino saloons use more equity financing) and turnover ratios. In spite of these differences the ROE is not significantly higher in regular casinos, as we expected. We believe that we found no significant differences in ROE between the two groups of casinos since regular casinos were involved in processes of compulsory settlements, which has led to their rationalization.

The ROE could be improved by increasing the net income, focusing on possibilities of increasing total revenues and/or decreasing costs. Considering the fact that during the times of the latest financial crisis, casinos already made cost reductions, we believe that there is a limited room for further reductions. Taking into account the current situation in the industry, there are also limited possibilities for improving the extent of recorded revenues. ${ }^{4}$ The Government of the Republic of Slovenia found already in 2010 that we need additional investments in the infrastructure to increase the number of guests. For example, Tingchi Liu et al. [16] state as one of the crucial future challenges for Macau (the most important casino center of the East) new projects including non-gaming facilities. Most of the new projects in Macau have some non-gaming amenities. For Atlantic City casino industry O'Donnell et al. [17] found superior performance for larger casinos than smaller ones (evidence of economies of scale).

Since 2010 no extensive investments in the infrastructure were made to improve the extent of arrivals. We believe that in the latest 5-year period the ROE in the industry improved due to the improved economic situation. The latter lead to an increase in the number of guests - the extent of visitors is highly associated with the economic circumstances. We believe that a potential deterioration of the economic situation would lead to significantly worse financial results and additional dismissal of employees in the Slovene casino industry.

Since Ivankovič and Jerman [15] found that financial performance of regular casinos and casino saloons was different in the period 2005-2009, we will compare the ROE of all casinos from the period 2013-2017 with their results from the period 2005-2008. Thus, we will find out if there is a significant difference in their performance over time. Since the period 2013-2017 is characterized as the period after the financial crisis, our comparative analysis does not include the period of crisis (2009-2012). ${ }^{5}$

To find out if there is any significant difference in the ROE of analyzed casinos over time, we performed a paired sample non-parametric t-test. Firstly, we present the descriptive statistics of the sample (Table 2).

$4 \quad$ In accordance with the findings of Prentice et al. [18] there is a gap in the literature from the field of casino offerings, gambling behaviours and profitability.

$5 \quad$ As can be noticed from the Appendix 6, the value of total revenues and total assets in the industry declined in 2009 in comparison with 2008. That is why we believe that the year 2009 was the first year of the crisis in this industry. 


\begin{tabular}{|l|c|c|c|c|}
\hline & 2005 & 2006 & 2007 & 2008 \\
\hline Average ROE - whole sample & 18.23 & 29.47 & 10.33 & 18.54 \\
\hline Median ROE - whole sample & 27.20 & 14.79 & 9.17 & 7.78 \\
\hline Standard deviation - whole sample & 49.41 & 57.37 & 75.78 & 46.16 \\
\hline Average ROE - regular casinos & 9.25 & -7.98 & -34.71 & -5.20 \\
\hline Median ROE - regular casinos & 6.02 & -0.92 & -6.57 & -4.70 \\
\hline Standard deviation - regular casinos & 7.37 & 22.86 & 56.69 & 51.04 \\
\hline Average ROE - casino saloons & 19.92 & 36.07 & 17.44 & 22.10 \\
\hline Median ROE - casino saloons & 27.97 & 18.12 & 15.44 & 9.34 \\
\hline Standard deviation - casino saloons & 53.88 & 59.44 & 77.14 & 45.72 \\
\hline
\end{tabular}

Table 2: ROE of regular casinos and casino saloons for the period 2005-2008 (in \%) Source of data: [14]

The average and median ROE for the sample are positive. The comparison between regular casinos and casino saloons shows that the average and median values are higher in the case of casino saloons. The casino saloons evidenced positive average and median values of ROE in the whole period, i.e. 2005-2008. On the other hand, regular casinos had in three out of four years' negative average and median values of ROE. Data indicate that casino saloons were more profitable for their owners in comparison with regular casinos.

The analysis with paired-sample t-test shows that there is a statistically significant difference $(0.003<0.05)$ between ROE in the two periods of analysis (Table 3$)$. Since the median value of ROE is lower in the period 2013-2017 in comparison with the period 2005-2008, our results indicate that in times before the crisis the casino industry was more profitable in comparison with the latest five-year period. Thus, we can confirm our second hypothesis, that the financial performance of the casinos (measured with ROE) deteriorated.

\begin{tabular}{|c|l|c|l|}
\hline Null hypothesis & Test & Sig. & \multicolumn{1}{c|}{ Decision } \\
\hline $\begin{array}{l}\text { The median of differences between } \\
\text { the period_1 and period_2 equals 0 }\end{array}$ & $\begin{array}{l}\text { Related Samples Wilcoxon } \\
\text { Signed Rank test }\end{array}$ & 0.003 & $\begin{array}{l}\text { Reject the null } \\
\text { hypothesis }\end{array}$ \\
\hline
\end{tabular}

Table 3: Wilcoxon Signed-rank test

Source: Author's own calculations

Since we found that the financial performance of casinos deteriorated and that in the latest fiveyear period the average ROE for the industry was negative in two out of five years (Appendix 1), it shows that the financial results are far from being good. This fact confirms statements of the Gaming Association of Slovenia that the casino industry is facing financial problems. This is why the Government should implement several goals presented in the Strategy of the development of games of chance in Slovenia. To date, the strategy has not yet been implemented in practice.

In evaluating performance of business operations of the selected companies, we grounded our analysis only on monetary indicators. In assessing the business, it would be worthwhile to consider also non-monetary indicators. In accordance with Milost [19] non-monetary measures are an important complement to financial one (different performance measurement systems are discussed by Janeš [20]). This is the most important limitation of our study. 


\section{PROPOSALS FOR IMPROVEMENT}

In the Strategy of Slovenian tourism for the period 2012-2016, gambling industry was defined as part of an integral tourist offer. The Strategy stated that organizing special games of chance significantly complements the Slovenian tourist offer [21]. The latest strategy of Slovenian tourism, i.e. The Strategy for the Sustainable Growth of Slovenian Tourism for the period 2017-2021 no longer gives gambling such an emphasis [9].

In practice, the gambling industry is not sufficiently integrated into the Slovenian tourist offer, which is an obstacle to achieving greater competitiveness of Slovenian tourism. Therefore, the specific objectives that should be pursued are [21, p. 53]:

- to support the development of infrastructure through a stimulative taxation system,

- to provide a high quality and diverse range of gaming products,

- introduce an active concession policy,

- to create gaming areas.

Since the adoption of the Strategy of the Development of Games of Chance in Slovenia in 2010, the goals in the field of gambling have not yet been realized. The taxation system for special games of chance has not been changed, the gambling offer has not improved significantly, gaming areas have not been formed, no changes have been detected in the concession policy system. Unless the stated goals will be implemented in practice, Slovene gambling industry will not increase its competitiveness.

At the same time, it is necessary to promote responsible gambling. In accordance with European Casino Association [22] it involves strategies that reduce gambling-related harm and increase gambling-related benefits across society.

\section{CONCLUSIONS}

The analysis showed that in the period 2013-2017 (as opposed to our expectations), there are no statistically significant differences in the financial performance between regular casinos and casino saloons. The operations of both groups of casinos in this period cannot be marked as very successful. However, it is encouraging that the performance of their business has improved in recent years. We also found that there is a statistically significant difference in the performance of casinos in the period following the financial crisis in comparison to the pre-crisis period. In the pre-crisis period, casinos were more successful in their operations. The results show that the performance of the casino business has significantly deteriorated over time. The aforementioned deterioration was also highlighted by the Association of gambling in Slovenia.

The data presented in the analysis showed a decrease in revenues (due to a decrease of guests and/or lower spending of guests), a decrease in the value of total assets and a lower return on investment than in the past. The reduction in the number of active concessions in the industry is the result of the termination of business of certain casinos. Since the beginning of the financial crisis, the number of employees has also significantly decreased. Since the industry is important for the Slovenian economy, it will be necessary to take appropriate actions as soon as possible. In 2010, the Government adopted the Strategy of the development of games of chance in Slovenia, where different crucial measures to improve the situation in the industry were stated. To date, the strategy has not been actively implemented in practice. 
Future studies will be able to show how potential Government actions will improve the situation in the industry. Future studies could also explore the financial performance of casinos in neighboring countries, which represent the greatest competition to Slovenian casinos. This kind of analysis could determine in which areas improvements and good practices from abroad could be transferred to the Slovenian environment.

\section{APPENDIX}

\begin{tabular}{|l|r|r|r|r|r|}
\hline & \multicolumn{1}{|c|}{2013} & \multicolumn{1}{c|}{2014} & \multicolumn{1}{c|}{2015} & \multicolumn{1}{c|}{2016} & \multicolumn{1}{c|}{2017} \\
\hline Average - whole sample & -28.13 & -30.91 & 74.52 & 1.90 & 18.63 \\
\hline Standard deviation - whole sample & 112.91 & 181.13 & 262.54 & 20.70 & 28.90 \\
\hline Average - regular casinos & -180.75 & -320.34 & 413.51 & 9.87 & 19.47 \\
\hline Standard deviation - regular casinos & 308.29 & 543.82 & 696.45 & 3.99 & 10.45 \\
\hline Minimum - regular casinos & -536.68 & -947.98 & 4.35 & 7.49 & 11.66 \\
\hline Maximum - regular casinos & 2.72 & 10.41 & 1217.66 & 14.47 & 31.34 \\
\hline Average - casino saloons & -9.06 & 3.82 & 33.85 & 0.90 & 18.53 \\
\hline Standard deviation - casino saloons & 52.25 & 23.17 & 145.04 & 21.76 & 30.57 \\
\hline Minimum - casino saloons & -136.77 & -59.85 & -56.04 & -53.77 & -15.84 \\
\hline Maximum - casino saloons & 107.65 & 37.73 & 722.09 & 36.97 & 141.51 \\
\hline
\end{tabular}

Appendix 1: ROE of regular casinos and casino saloons in the period 2013-2017. (in \%) Source: data are gathered from the database of GVIN [14]

\begin{tabular}{|l|r|r|r|r|r|}
\hline & \multicolumn{1}{|c|}{2013} & \multicolumn{1}{c|}{2014} & \multicolumn{1}{c|}{2015} & \multicolumn{1}{c|}{2016} & \multicolumn{1}{c|}{2017} \\
\hline Standard deviation - whole sample & 20.78 & 13.02 & 11.89 & 12.16 & 16.92 \\
\hline Average - regular casinos & -3.86 & -6.35 & 6.51 & 1.70 & 4.09 \\
\hline Standard deviation - regular casinos & 5.07 & 7.58 & 8.68 & 0.69 & 2.09 \\
\hline Minimum - regular casinos & -9.57 & -14.25 & 1.06 & 0.91 & 2.03 \\
\hline Maximum - regular casinos & 0.12 & 0.86 & 16.52 & 2.20 & 6.21 \\
\hline Average - casino saloons & -4.84 & 1.22 & 3.14 & -0.01 & 8.61 \\
\hline Standard deviation - casino saloons & 21.99 & 13.40 & 12.31 & 12.91 & 17.91 \\
\hline Minimum - casino saloons & -88.45 & -42.62 & -23.29 & -38.00 & -11.88 \\
\hline Maximum - casino saloons & 18.34 & 19.29 & 21.51 & 24.34 & 83.50 \\
\hline
\end{tabular}

Appendix 2: ROA of regular casinos and casino saloons in the period 2013-2017. (in \%) Source: data are gathered from the database of GVIN [14]

\begin{tabular}{|l|r|r|r|r|r|}
\hline & \multicolumn{1}{|c|}{2013} & \multicolumn{1}{c|}{2014} & \multicolumn{1}{c|}{2015} & \multicolumn{1}{c|}{2016} & \multicolumn{1}{c|}{2017} \\
\hline Average - whole sample & 41.29 & 45.55 & 46.23 & 43.90 & 52.15 \\
\hline Standard deviation - whole sample & 27.90 & 25.88 & 28.95 & 32.80 & 25.16 \\
\hline Average - regular casinos & 12.53 & 7.31 & 17.09 & 18.93 & 24.09 \\
\hline Standard deviation - regular casinos & 10.89 & 16.65 & 7.71 & 7.89 & 10.65 \\
\hline Minimum - regular casinos & 4.91 & -10.08 & 11.99 & 11.97 & 14.54 \\
\hline Maximum - regular casinos & 25.00 & 23.11 & 25.96 & 27.50 & 35.58 \\
\hline Average - casino saloons & 44.74 & 50.14 & 49.72 & 46.90 & 55.66 \\
\hline Standard deviation - casino saloons & 27.38 & 22.93 & 28.62 & 33.44 & 24.29 \\
\hline Minimum - casino saloons & 5.97 & 9.03 & -40.46 & -66.18 & 11.38 \\
\hline Maximum - casino saloons & 91.04 & 83.65 & 91.06 & 90.37 & 88.63 \\
\hline
\end{tabular}

Appendix 3: Share of equity in the funding structure of regular casinos and casino saloons in the period 2013-2017. (in \%)

Source: data are gathered from the database of GVIN [14] 
FINANCIAL PERFORMANCE OF SLOVENE CASINO INDUSTRY: COMPARATIVE ANALYSIS OF REGULAR CASINOS AND CASINO SALOONS

\begin{tabular}{|l|r|r|r|r|r|}
\hline & \multicolumn{1}{|c|}{2013} & \multicolumn{1}{c|}{2014} & \multicolumn{1}{c|}{2015} & \multicolumn{1}{c|}{2016} & \multicolumn{1}{c|}{2017} \\
\hline Standard deviation - whole sample & 35.31 & 22.22 & 16.29 & 17.18 & 13.12 \\
\hline Average - regular casinos & -5.60 & -6.21 & 5.06 & 1.71 & 3.71 \\
\hline Standard deviation - regular casinos & 7.29 & 6.92 & 5.57 & 0.56 & 1.04 \\
\hline Minimum - regular casinos & -13.81 & -12.51 & 1.19 & 1.22 & 2.51 \\
\hline Maximum - regular casinos & 0.10 & 1.20 & 11.44 & 2.32 & 4.35 \\
\hline Average - casino saloons & -12.99 & -3.61 & 0.11 & -3.35 & 3.87 \\
\hline Standard deviation - casino saloons & 37.31 & 23.47 & 17.12 & 18.14 & 13.94 \\
\hline Minimum - casino saloons & -138.56 & -66.65 & -45.19 & -49.28 & -45.46 \\
\hline Maximum - casino saloons & 25.75 & 29.34 & 25.85 & 25.14 & 22.29 \\
\hline
\end{tabular}

Appendix 4: Net profitability of revenues

of regular casinos and casino saloons in the period 2013-2017. (in \%)

Source: data are gathered from the database of GVIN [14]

\begin{tabular}{|l|r|r|r|r|r|}
\hline & \multicolumn{1}{|c|}{2013} & \multicolumn{1}{|c|}{2014} & \multicolumn{1}{c|}{2015} & \multicolumn{1}{c|}{2016} & \multicolumn{1}{c|}{2017} \\
\hline Average - whole sample & 0.94 & 0.98 & 1.08 & 1.14 & 1.09 \\
\hline Standard deviation - whole sample & 0.60 & 0.50 & 0.45 & 0.68 & 0.74 \\
\hline Average - regular casinos & 0.91 & 0.96 & 1.07 & 1.04 & 1.05 \\
\hline Standard deviation - regular casinos & 0.32 & 0.33 & 0.37 & 0.36 & 0.29 \\
\hline Minimum - regular casinos & 0.72 & 0.74 & 0.77 & 0.77 & 0.83 \\
\hline Maximum - regular casinos & 1.28 & 1.33 & 1.48 & 1.45 & 1.38 \\
\hline Average - casino saloons & 0.94 & 0.99 & 1.08 & 1.15 & 1.10 \\
\hline Standard deviation - casino saloons & 0.63 & 0.53 & 0.47 & 0.72 & 0.78 \\
\hline Minimum - casino saloons & 0.14 & 0.13 & 0.29 & 0.23 & 0.20 \\
\hline Maximum - casino saloons & 2.88 & 2.37 & 2.26 & 3.76 & 4.28 \\
\hline
\end{tabular}

Appendix 5: Asset turnover of regular casinos and casino saloons in the period 2013-2017.

Source: data are gathered from the database of GVIN [14]

\begin{tabular}{|l|c|c|c|c|c|}
\hline Casino industry & \multicolumn{1}{|c|}{2005} & 2006 & 2007 & 2008 & \multicolumn{1}{c|}{2009} \\
\hline Total revenues & 280.292 .943 & 297.017 .380 & 293.176 .891 & 297.657 .734 & 262.441 .641 \\
\hline Total assets & 317.455 .100 & 344.901 .626 & 437.726 .127 & 458.820 .140 & 420.598 .298 \\
\hline
\end{tabular}

Appendix 6: Total revenues and total assets in the casino industry in the period 2005-2009. (in $€$ ) Source: data are gathered from the database of GVIN [14] 


\section{REFERENCES}

[1] Sallaz, J.J. (2006) The making of the global gambling industry: An application and extension of the field theory. Theory and Society, Vol. 35, No. 3, pp. 265-297.

[2] Eadington, W.R. (2008) Gambling policy in the European Union: Monopolies, market access, economic rents, and competitive pressures, among gaming sectors in the Member States. In: Coryn, T., Fijnaut, C. and Littler, A. Economic aspects of the gambling regulation: EU and US perspectives. Lieden: Martinus Nijhoff Publishers, pp. 71-90.

[3] Government of the Republic of Slovenia (2010) Strategy of the development of games of chance in Slovenia. Available at: http://www.fu.gov.si/drugo/posebna_podrocja/igre_na_ sreco/

[4] AJPES (2010) Financial data. Available at: https://www.ajpes.si/fipo/

[5] Repinc, T. (2014) Gaming Association of Slovenia sees a perspective: 1,000 new jobs in gambling activities. Available at: https://www.gzs.si/mediji/Novice/ArticleId/38408/zdruzenje-igralnistva-slovenije-vidi-perspektivo--1000-novih-delovnih-mest-v-igralniski-dejavnosti

[6] Gambling Act, Official Gazette of the Republic of Slovenia 85/2001.

[7] La Rosa, F., Bernini, F. (2018) Corporate governance and performance of Italian gambling SMEs during recession. International Journal of Contemporary Hospitality Management, Vol. 30, No. 3, pp. 1939-1958.

[8] Statistical Office of the Republic of Slovenia (2018) Number of tourists arrivals and overnight stays. Available at: https://www.stat.si/StatWeb/Field/Index/24

[9] Ministry of Economic Development and Technology (2017) Strategy for Sustainable Growth of Slovenian Tourism 2017-2021. Available at: http://www.mgrt.gov.si/fileadmin/ mgrt.gov.si/pageuploads/12-12-2017-KONCNO_STRATEGIJA_TURIZEM_popravek_ za_splet_9.10.2017.pdf

[10] Assaf, G.A., Knezevic Cvelbar, L. and Pahor, M. (2013) Performance drivers in the casino industry: Evidence from Slovenia. International Journal of Hospitality Management, Vol. 32, pp. 149-154.

[11] Pahor, M. (2007) The impact of gambling on social and economic environment in Nova Gorica. Available at: https://www.researchgate.net/publication/228926594_The_impact_ of_gambling_on_social_and_economic_environment_in_Nova_Gorica

[12] Agency of the Republic of Slovenia for Public Legal Records and Related Services - AJPES (2018) Financial data. Available at: Http://www.ajpes.com

[13] Agency of the Republic of Slovenia for Public Legal Records and Related Services - AJPES (2018) Information about the performance of companies in Slovenia in 2017. Available at: https://www.ajpes.si/Doc/LP/Informacije/Informacija_LP_GD_zadruge_2017.pdf

[14] GVIN (2018) Financial data. Available at: https://www.bisnode.si/produkti/bisnode-gvin/

[15] Ivankovič, G. and Jerman, M. (2011) Financial performance analysis within Slovene gambling industry. In: Sustainable Tourism: Socio-Cultural, Environmental and Economic Impact, pp. 107-119.

[16] Tingchi Liu, M., Tsing Gya Chang, T., Loi, E.H.N., Chi Hong Chan, A. (2015) Macau gambling industry: current challenges and opportunities next decade. Asia Pacific Journal of Marketing and Logistics, Vol. 27, No. 3, pp. 499-512.

[17] O'Donnell, J.M., Lee, S., Roehl, W.S. (2012) Do economies of scale exist in the Atlantic City casino industry? International Journal of Contemporary Hospitality Management, Vol. 24, No. 1, pp. 62-80. 
[18] Prentice, C., IpKin, A., Desmond Lam, W. (2017) Uncovering the service profit chain in the casino industry. International Journal of Contemporary Hospitality Management, Vol. 29, No. 11, pp. 2826-2846.

[19] Milost, F. (2013). Information Power of Non-Financial Performance Measures. International journal of business management and economic research, Vol. 4, No. 6, p. 823-828.

[20] Janeš, A. (2014) Empirical verification of the balanced scorecard. Industrial Management \& Data Systems, Vol. 114, No. 2, pp. 203-219.

[21] Government of the Republic of Slovenia (2012) Strategy of Development of Slovenian Tourism 2012-2016. Partnership for Sustainable Development of Slovenian Tourism. Available at: http://www.mgrt.gov.si/fileadmin/mgrt.gov.si/pageuploads/turizem/Turizem-strategije_politike/Strategija_turizem_sprejeto_7.6.2012.pdf

[22] European Casino Association (2016) Position Paper on Responsible Gambling. Available at: http://www.europeancasinoassociation.org/fileadmin/eca-files/New_position_papers_-_December_2016/ECA_position_paper_on_Responsible_Gambling.pdf 